\title{
Discussion on the British and American Literature Education from the Perspective of Ecological Linguistics
}

\author{
Xinli Shi \\ College of foreign languages, Ningxia Normal University, Ningxia, 756000, China
}

Keywords: Ecological linguistics, British and American Literature, Education.

\begin{abstract}
As an important part in literature education, British and American literature education not only can let students fully feel the beauty of different language environment, but also can help students greatly improve their perceptivity on literature knowledge. On the basis of British ans American literature education's focus on language, the general literature workers start trying to get into teaching from the ecological linguistics angle to realize the further enhance on British and American literature education value. Therefore, the author analyzes relevant strategies on British and American Literature education from the perspective of ecological linguistics theory. This is for reference only, your comment is appreciated.
\end{abstract}

\section{Introduction}

As an important research achievement in the cultural ideology of British and American countries, British and American literature not only can reflect the social characteristics in a certain period on a certain level, but also can be an important carrier of English language expression, with a profound cultural deposits. Look from the literary form, literature works not only contain differences on living environment, morals appearance and other factors of various populations, also bear different individual's thoughts and feelings under different situations, features of literature works on ecological and linguistics are pretty obvious. British and American literature education in undergraduate phase, besides making a preliminary appreciation on literature works, also need an analysis from a targeted angle. This paper has carried out related discussions on British and American literature education from the perspective of ecological linguistics, summarized as follows.

\section{Description on relevant concepts of ecological linguistics}

\section{The concept of ecological linguistics.}

Ecological linguistics mainly refers to integrate linguistics and ecology organically, to make it become a comprehensive language research system, can be an important branch of linguistics. The concept of ecological linguistics was first put forward by a Norwegian linguist, this linguist believed that ecology is not a stationary state, it can be used for analogy with language environment, research on the mutual influence between the ecology and linguistics can be a mainstream model in linguistic ecology. See from the development status of ecological linguistics, "ecology" and "language" are not two separate research objects, but the product of their integration, mainly takes ecological environmental changes and language development as essential theory, it has gradually developed into a kind of institutionalized field.

The features of ecological linguistics.

A). Diversity. In the ecological language system, diversity is a macro feature, specifically contains language environment and internal elements. Researches show that on the basis of convergence between biology and language, under the ecological environment with higher degree of biological diversity, the diversification level of language is also relatively higher, to some extent, it can symbolize the development, adjustment and correlation of ecological system and language system $^{[1]}$.

B). Integrality. Factors in language environment are various, this means that the establishment of this environment is based on the mutual restriction and coadjustment of different factors, therefore, it 
cannot be studied as an isolated system, but should be regarded as a unified whole ${ }^{[2]}$. Under the overall influence of ecological language environment, speakers' scene orientationto and different social and economic characteristics can present an interconnected state, it has important supporting role on the establishment of language data.

\section{Education strategy for British and American education from the perspective of ecological linguistics}

\section{Construct interest platform to stimulate students' subjective initiative.}

The ecological education of British and American literature is mainly supported by literature works and ecological linguistics theories, with constructing integral diversified ecological education system as core objective ${ }^{[3]}$. However, the realization of core teaching objectives usually cannot be separated students' subjective initiative, how to stimulate the subjective initiative with proper method becomes the key factor for the smooth implementation of teaching work. According to the current implementation status of British and American literature education, no matter education workers or students, most of them are lack of ecological consciousness, this directly caused the difficult implementation of emotion communication and view exchange in the British and American literature education, which is not benefit to the construction of whole ecological teaching system. Hereto, teachers can fully inject aesthetic taste and humanistic quality into the teaching through constructing interest platform for students, thus to complete the fundamental innovation from teaching idea to teaching model. The construction of teaching interest platform should be based on students' adequate understanding on teaching contents, during this process, teachers can carry out teaching through interactive forms like role play and debate thinking, students can express personal views to complete the literature works analysis from different perspectives.

For example, A Tale of Two Cities of Charles Dickens, this work main sets "Paris" and "London" as main lines, through the description and analysis on the historical background to present the emergence of various thoughts and different class struggles, it occupies an important status in the history of literature. In order to guide students to learn and appreciate this work from subjective perspective, teachers can start from construct interest platform under the ecological language environment to guide students to describe different characters through opera performance to complete the exploration course on characters' inner world. For example, a typical character in the work--Carton, his heart is full of complaints against the dirty world, but he is filled with frustration of unable to fight in the overall situation, after falling love with beautiful and kind Lucy, he chooses to hide his hot feelings through blessing, at last, for Lucy's happiness he choose to replace Lucy's lover to go for the guillotine. During the expressing process of this character, students can extract the typical fragment as drama lines and play it, for example, sentences like "For you,for the one you love,I am willing to do anything." are important embodiment of characters' inner feeling, which can provide important direction for the multi-angle expression of language. In addition to this, teachers can use this work as a theme to lead students to explain their personal views through debate, for example, in the understanding on character "Darnay", students can notice that as the descendant of important villain in this work, Darnay is an ideal image of hating evil as one's enemy and having integrity, he keeps consistent good faith and zeal during his love with Lucy. As Lucy's father--Dr.Maynette, his thoughts and feelings are complicated when facing the son of his enemy, but at last he is moved by Darnay' s sincerity and he chooses to bless for his daughter. Teachers' guidance in students' debate can start from above story background, set "whether return good for evil desirable" as theme, encourage students to actively explain their personal views, thus to deeply analyze character features and images from different angles. The above method can realize the purpose of leading students into the works through constructing interest platform for students, it also can stimulate students' subjective initiative, to lay a good foundation for improving appreciate level of British and American literature. 


\section{Construct ecological environment to play the leading role of teaching.}

As a kind of complicated ecological cycle, the ecological education of British and American education usually needs to be based on the construction of ecological environment to realize the correlation among different ecological factors in the educational environment ${ }^{[4]}$. From the features of teaching ecological environment, we can see that classroom atmosphere, teacher-student relationship, teaching model are under state of mutual influence, every factor is the indispensable part in ecological language teaching environment. Therefore, in order to realize the full play of the dominant function of teaching, we can start from the perspective of constructing ecological environment to complete the interaction among different individuals (such as students and students, students and teachers, students and works) to realize the optimal of ecological environment and atmosphere. From the specific requirements of teaching ecological environment, we can found that the interactive pattern among ecological factors is condition on each other, they can have direct influence on each other, the improvement of the whole pattern cannot leave the comprehensive development of all factors. Therefore, teachers can start from the perspective of constructing harmonious and ecological studying environment to provide important background conditions for students' appreciation on British and American literature works, thus to give full play of the dominant function of teaching.

For example, Lawrence' s Odor of Chrysanthemums, this is a short story with milestone meaning in Lawrence' $s$ writing career, it sets the miners family in English village in the $20^{\text {th }}$ century as background to carry out a series of stories of the working class under the industrial revolution. In this novel, the writer focuses on the description of the local conditions and customs of the protagonist's hometown, Nottinghamshire, to reveal the British villages under relevant historical background to the readers, thus to strengthen the third dimension of the whole story. Under the cultural environment, historical environment and realistic environment, different characters have different vivid labels, the social consciousness also sets people thinking. In order to help students deeply understand the literacy heritage in this work ,teachers can be with the help of multimedia equipment to present literature works to students in a more intuitive state. For example, under the situation that students fully understand the historical background of the literature work, teachers can collect relevant life fragments or photos of the working class in 20th century and play them to students with multimedia equipment to help students have a profound recognition and understanding on the background and lifestyle in different eras. As everyone knows, any form of literary creation is inalienable with the social development status at that time, this indicates the important influence of historical background on British and American literature works, specific understanding on historical background also becomes an important path to deeply analyze British and American literature works. The above method constructs ecological environment for students, on one hand, it can furtherly highlight emotional expressions in literature works, on the other hand, it can stimulate the further play of the dominant function of teaching, produces important performance that echos to the teaching of British and American literature.

\section{Deeply dig essence to improve students' literature appreciation.}

The improvement of literature appreciation is the basic target of British and American literature education, is also a kind of aesthetic expression with literature as carrier. Therefore, in the activity of British and American literature education, teachers should lead students to deeply dig the essence of relevant works, and devote themselves into helping students improve literature appreciation and aesthetic realm. From the essence of literature education, we can see that pure language study and analysis will lead education work fall into narrowness, only the deep analysis, dig of the literature connotation can realize the highly integration of teaching and studying. On one hand, teachers can start from stimulating students' emotional factor to guide students for personal thinking through exploring philosophy and value in the work; on the other hand, teachers can start from stimulating students' extension level to complete rational speculative behavior through stimulating students' communication consciousness on different levels to help students establish harmonious and unified ecological character in the literature education process.

For example, Shakespeare's King Lear, this is one of the classic "Four great tragedies", it mainly describes Ling Lear's measurement criteria, distribution outcomes on his three daughters' dowry 
distribution to express the difference of different people on emotional expression and material needs, thus to arouse people's deep thinking on the topic of "humanity". In this work, King Lear use his daughters' expression way of love as measurement criteria to observe his daughters' love for him, this measurement is no doubt lack of objectivity, while King Lear doesn't realize that the language form, under different situation its functions are also different, humanity under positive language might be negative. While like the old saying "There are a thousand Hamlets in a thousand people's eyes.”, thoughts and feelings under different perspectives are also different, in order to help students improve literature appreciation, teachers can encourage students to start from themselves to make analysis on this work to complete the appreciation progress. Through approximately understanding on the work plot, students can make deep analysis on King Lear's final tragedy origin from personal perspective, such as too subjective, imperious and despotic, to presume King Lear's mental activity changes through writing book report. After appreciation, teachers also can appreciate through guiding students' interactive communication, thus try to eliminate the limitation in the appreciation process. Above method guide students to deeply dig the literature works to complete students' deep analysis on literature works, meanwhile it matches with the objective of students' literature appreciation and has important auxiliary significance on the optimal implementation of the whole teaching engineering.

\section{Conclusions}

In conclusion, carrying out British and American literature education from the perspective of ecological language theory can realize the organic integration of teaching work and ecological environment, it has important supporting meaning for the construction of literature education ecological environment. During teachers' British and American literature education process from this perspective, except for fully respecting the subject of ecological education, we should also permeate multi-culture consciousness into the teaching work, essentially to stimulate students' aesthetic realm and promote the revolution and development of British and American literature education.

\section{References}

[1] Ye Mingzhu. Discussion on the Teaching Model of British and American Literature under the Background of Quality Education, Track-and-field Teaching(mid-month), 2013,21(8):182-183.

[2] Su Yu. Thinking on the Hidden Curriculum British and American Literature under the Background of English Reform, Education and Teaching Forum, 2015(44):199-200.

[3] Hu Hui. Exploring on British and American Literature--Setting Shakespeare's Literature Works as Examples, Theatrical Family, 2015(09):226.

[4] Cao Xiaoling. Research on the British and American Literature under the Perspective of Ecological Linguistics, Educational Theory and Practice, 2015, 35(24):56-57. 